African Crop Science Journal by African Crop Science Society is licensed under a Creative Commons Attribution 3.0 Uganda License. Based on a work at www.ajol.info/ and www.bioline.org.br/cs DOI: https://dx.doi.org/10.4314/acsj.v29i1.11

\title{
FARMERS' PERCEPTIONS OF CLIMATE CHANGE AND ADAPTATION STRATEGIES ON SORGHUM PRODUCTIVITY IN THE SUDANIAN AND SAHELIAN ZONES OF MALI
}

\author{
L. TRAORÉ ${ }^{1,2}$, O.D. BELLO ${ }^{1,5}$, A. TOGOLA ${ }^{2}$, I. BALOGOUN ${ }^{1,3}$, F. CHABI $^{1}$, I. YABI ${ }^{4}$, \\ E.L. AHOTON ${ }^{5}$ and A. SAÏDOU ${ }^{1}$
}

${ }^{1}$ Unité de Recherche sur la Gestion Durable des Sols et des Cultures (ISCM), Laboratoire des Sciences du Sol, Ecole des Sciences et Techniques de Production Végétale (ESTPV), Faculté des Sciences Agronomiques (FSA), Université d'Abomey-Calavi (UAC), 04 BP 1510 Cadjèhoun, Cotonou, Bénin

${ }^{2}$ Laboratoire d'Agro-Physio-Génétique et de Biotechnologie végétale, Institut Polytechnique Rurale de Formation et de Recherche Appliquée (IPR/IFRA) de Katibougou, BP 06, Mali ${ }^{3}$ Ecole de Gestion et de Production Végétale et Semencière (EGPVS), Université Nationale d'Agriculture (UNA), BP 43 Kétou, Bénin

${ }^{4}$ Laboratoire Pierre PAGNEY «Climat, Eau, Ecosystème et Développement », Faculté des Sciences Humaines et Sociales, Département de Géographie et Aménagement du Territoire, Université d'Abomey-Calavi (UAC), BP 526 RP Cotonou, Bénin

${ }^{5}$ Laboratoire de Biologie Végétale, Ecole des Sciences et Techniques de Production Végétale (ESTPV), Faculté des Sciences Agronomiques (FSA), Université d'Abomey-Calavi (UAC), BP 526 RP Cotonou, Bénin

Corresponding author: saidoualiou64@gmail.com

(Received 21 May 2020; accepted 25 January 2021)

\begin{abstract}
In Mali, climate change is a major threat to the productivity of food security crops such as sorghum (Sorghum bicolor (L.) Moench, 1794). The objective of this study was to analyse farmers' perceptions of climate change effects, on sorghum productivity and the adaptation related strategies. A total of 352 sorghum farmers in the Sudanian and Sahelian zones of Mali were interviewed, using a semistructured questionnaire. Data collected were related mainly to the farmers' socio-economic profiles, indicators used to characterise climate change and strategies developed to cope with it. Irregular rainfall, marked rise in temperatures and early cessation of the rainy seasons were the main manifestations of climate change effects according to the respondents. These effects reportedly resulted in a drastic drop in sorghum yields. Use of meteorological information (19.89\% of the respondents), use of early and drought-resistant varieties (13.35\% of the respondents), and intercropping of sorghum with other crops $(25.85 \%$ of the respondents) were the strategy options adapted by farmers. The choice of an adaptation strategies was largely dependent on the number of years of experience in sorghum production, and the number of labour providers available in the household. It is imperative to assess
\end{abstract}


and refine the agronomic effectiveness of these coping strategies to improve sorghum productivity in the study areas.

Key Words: Adaptation strategies, rainfall irregularity, Sorghum bicolor

\section{RÉSUMÉ}

La présente étude vise à déterminer l'effet des changements climatiques sur la productivité du sorgho (Sorghum bicolor (L.) Moench, 1794) et les stratégies d'adaptations mises en œuvre par les agriculteurs au Mali. Ainsi, les enquêtes ont été effectuées dans 32 villages dans les deux zones. 352 producteurs de sorgho âgés de 25 à 75 ans tant dans la zone soudanienne que dans la zone sahélienne ont été sélectionnés et soumis à un questionnaire semi structuré. Les producteurs observent de nos jours une irrégularité des pluies, des températures élevées, des vents violents, des arrêts précoces de la saison pluvieuse et des poches de sécheresse au cours de la saison, et des inondations $(85,70 \%)$ causant une baisse drastique des rendements des cultures du sorgho. Le suivi des informations météorologiques $(19,89 \%)$ dans les médiats, l'utilisation des variétés précoces et résistantes à la sécheresse $(13,35 \%)$, la pratique des associations culturales $(25,85 \%)$, la pratique des techniques de paillage $(2,27 \%)$ avec les résidus de récolte, l'apport des engrais minéraux et organiques $(24,72 \%)$, la pratique du zaï $(3,41 \%)$, les pratiques occultes $(3,98 \%)$ sont des stratégies d'adaptation mises en œuvre. Le choix des pratiques d'adaptation est significativement $(\mathrm{P}<0,05$ à $\mathrm{P}<0,001)$ déterminé par la situation matrimoniale de l'individu, de son expérience dans la production et des moyens financiers dont il dispose. L'étude suggère d'évaluer l'efficacité de ces stratégies d'adaptation pour une meilleure productivité du sorgho dans les deux zones d'étude.

Mots Clés: Stratégie d'adaptation, Irrégularité des pluies, Sorghum bicolor

\section{INTRODUCTION}

In Mali, climate change is a major threat to the productivity of food security crops such as sorghum (Sorghum bicolor (L.) Moench, 1794). Sorghum is the second most important dry cereal crop after millet (FAO, 2012; Sissoko et al., 2017). According to Sissoko et al. (2018), sorghum is the third most consumed cereal in Mali after millet and rice; and accounts for most of the country's agricultural land (Bazile and Soumaré, 2004). Despite this significance, the average sorghum yields obtained (around $1 \mathrm{t} \mathrm{ha}^{-1}$ ) on the farms are inadequate to meet the rising consumer demands (Sissoko et al., 2018).

The main constraints to viable development of the sorghum sector in Mali are unfavourable climate change effects (Traoré et al., 2001); coupled with the lack of efficient and drought resistant varieties (Sissoko et al., 2017). These factors seriously compromise the production of sorghum and limit the population's access to food in sufficient quantities. It is, thus imperative to implement mitigation measures and develop new strategies for adaptation to cope with the adverse effects of climate change (Barnabás et al., 2008; Traoré, 2014), especially commensurate with sorghum cultivation.

The adaptation practices currently used by farmers in response to the negative consequences of climate change are inefficient and largely depend on their perceptions and their endogenous knowledge (Dimon, 2008; Bello et al., 2017). The involvement of farmers in local actions to adapt to climate change is total, when these actions integrate their endogenous knowledge (Kanté, 2001). Taking this empirical knowledge into account in development policies, induces the effective participation of farmers (Bambara et al., 2013; Traoré, 2014; Bello et al., 2017). To mitigate the negative effects of climate change on 
sorghum productivity, it is therefore, necessary to define appropriate adaptation measures based on farmers' perceptions and practices (Mustapha et al., 2012).

The objective of this study was to analyse farmers' perceptions of the effects of climate change on sorghum productivity and the mitigation strategies implemented in the Sudanian and Sahelian zones of Mali.

\section{MATERIALS AND METHODS}

Study zone. A survey was conducted in Mali, in the districts of Koulikoro (Sudanian zone) and San (Sahelian zone) (Fig. 1). The Koulikoro district is located at $08.9^{\circ} 32^{\prime}$ West longitude and $12^{\circ} 56^{\prime}$ North latitude, at an altitude of $332 \mathrm{~m}$ above sea level, on the isohyet $900 \mathrm{~m}$. The climate of this site is SudanoSahelian, with a mean annual rainfall ranging between 700 and $900 \mathrm{~mm}$. The area is marked by a single rainy season, from mid-June to October (cropping period). More recently, there have been shifts in the rainy season, but the area registers an average of four months of rain per year. The vegetation is dominated by Faidherbia albida, Adansonia digitata, Vitelaria Paradoxa, Balanites aegyptiaca, Ceiba pentandra, Khaya senegalensis, Parkia biglobosa etc. The soils are clayey, sandy, lateritic and gravelly in some areas.

The district of San is located in the Sahelian zone at $04^{\circ} 09^{\prime}$ West longitude and $13^{\circ} 3^{\prime}$ North latitude, at an altitude of $287 \mathrm{~m}$ above sea level. The average annual rainfall oscillates between 500 and $800 \mathrm{~mm}$. The rainy season also begins in mid-June and ends in October. There is also a shift in the rainy season, with an average of 3 months of rain. The main types of soil of the area are tropical red ferruginous soils, yellow leached tropical ferruginous soils, deep hydromorphic ferruginous soils, and poorly developed alluvial soils.

The vegetation is characterised by wooded and shrub savannah in places. The herbaceous carpet is dominated by annual grasses. The main woody species encountered are Combretum lecardii, Combretum glutinosum,
Guiera senegalensis, Prosopis africana, Sclerocarya birrea, Spondias monbin and Adansonia digitata.

Criteria for choosing study villages. The interest in sorghum cultivation, the variation in the cropping systems, the perception of the effect of climate change on crop productivity, whether or not to adopt adaptation strategies to deal with the effects of climate change in production were the most important criteria in the selection of the villages surveyed. In addition to the criteria mentioned above, other criteria were added for the selection of farmers. These included land availability, accessibility of the area throughout the season, the cooperative spirit in working with the research team and the socio-cultural group. On this basis, 32 villages were drawn at random on the basis of 16 per district (Table 1). The survey was conducted among farmers on the basis of the town hall registers of the municipalities surveyed during the fourth General Population and Housing Census (RGPH) in 2009.

Sampling method. The sample size used was obtained using the normal approximation of the binomial distribution proposed by Dagnelie (1998):

$\mathrm{N}=\left[\left(\mathrm{U}_{1-\alpha / 2}\right)^{2} \times \mathrm{p}(1-\mathrm{p})\right] / \mathrm{d}^{2}$

Where:

U1- $\alpha$ / 2 the value of the normal random variable for a probability of value $1-\alpha / 2, \alpha$ being the risk of error.

For $\alpha=5 \%$, the probability $1-\alpha / 2=0.975$ and we have U1- $\alpha / 2=1.96$. $\mathrm{p}$ is the proportion of sorghum producers in the area and $\mathrm{d}$ is the estimation error margin, retained at $5 \%(1 \%<d<15 \%)$ in this study. From the $\mathrm{P}$ values obtained from the results of the exploratory phase of the study, a total of 352 producers were surveyed, including 176 producers in each of the two area. 


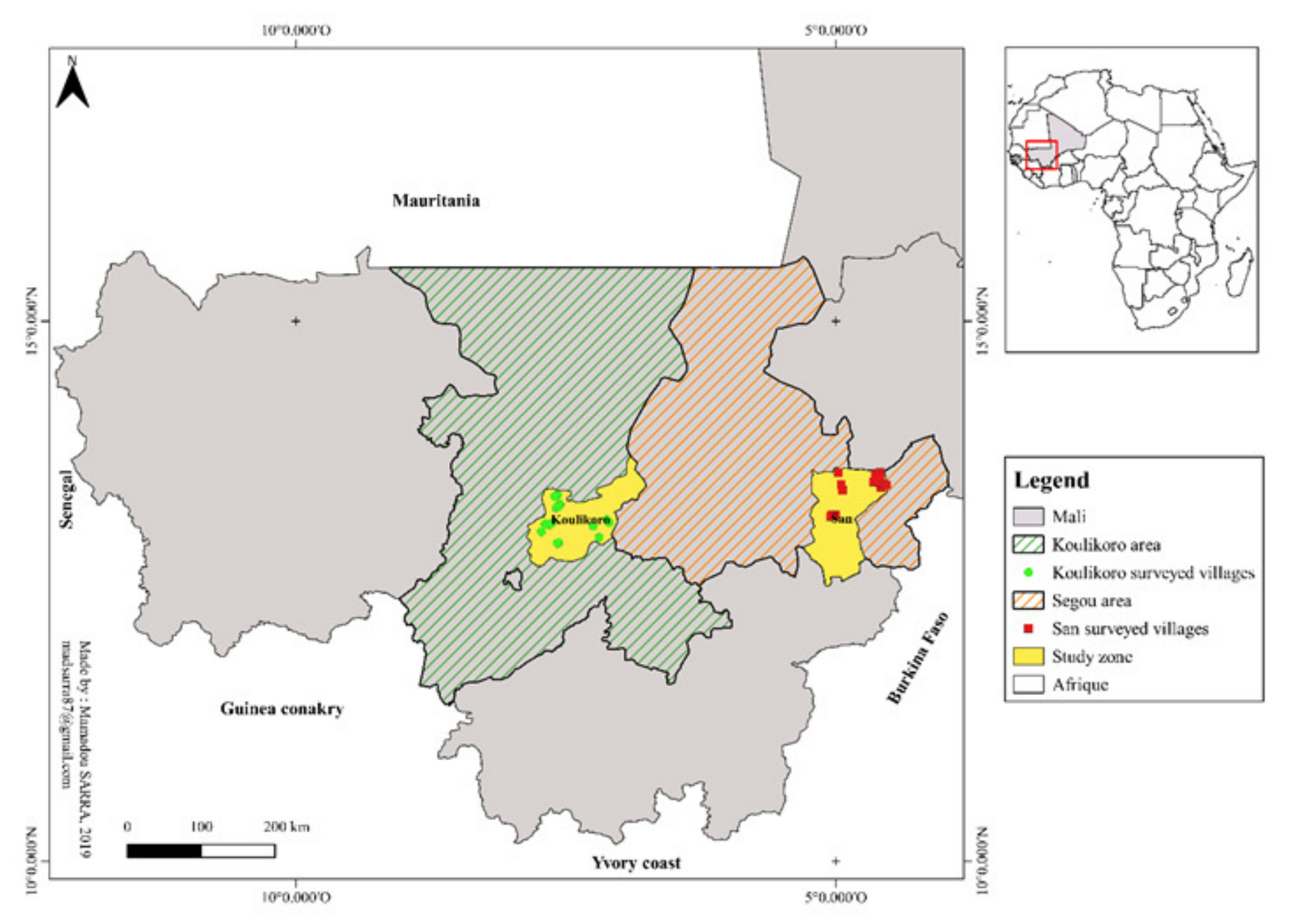

Figure 1. Geographic position of the villages surveyed in the two districts. 
TABLE 1. List of villages surveyed by district in Mali

\begin{tabular}{|c|c|c|c|}
\hline Region & District & Municipalities & Villages \\
\hline \multirow[t]{4}{*}{ Koulikoro } & Koulikoro & Koula & $\begin{array}{l}\text { Koula } \\
\text { Kabana } \\
\text { Wolonkotoba } \\
\text { Felou }\end{array}$ \\
\hline & & Sirakorola & $\begin{array}{l}\text { Sirakorola } \\
\text { Fantébougou } \\
\text { Koyo } \\
\text { Kalankoulou }\end{array}$ \\
\hline & & Dinangougou & $\begin{array}{l}\text { Kamani } \\
\text { Sassila } \\
\text { Kènènkou } \\
\text { Diakinèbougou }\end{array}$ \\
\hline & & Meguetan & $\begin{array}{l}\text { Chô } \\
\text { Tanabougou } \\
\text { Tiètigila } \\
\text { Sendo }\end{array}$ \\
\hline \multirow[t]{4}{*}{ Ségou } & San & Baramadou & $\begin{array}{l}\text { Baramadougou } \\
\text { Mayarasso Sonina } \\
\text { Kocoula } \\
\text { Paporoné }\end{array}$ \\
\hline & & Tene & $\begin{array}{l}\text { Diakani Marka } \\
\text { Fonokan } \\
\text { Tiéba } \\
\text { Bankouma Bobo }\end{array}$ \\
\hline & & Sy & $\begin{array}{l}\text { Gambia } \\
\text { Titama } \\
\text { Tougouni } \\
\text { Sy }\end{array}$ \\
\hline & & Niasso & $\begin{array}{l}\text { Niasso } \\
\text { Cinzo } \\
\text { Tontona } \\
\text { Koro }\end{array}$ \\
\hline Total & 2 & 8 & 32 \\
\hline
\end{tabular}


Thus, at the level of each district, four municipalities were surveyed, namely Dinandougou, Koula, Meguetan and Sirakorola for Koulikoro district; and Niasso, Baramadou, Sy and Tene for San district. In each municipality, four villages were randomly selected, making a total of 32 villages within the two districts. It was a three-stage random sampling, of which the municipalities constituted the primary unit, the villages, the secondary unit, and the households the tertiary unit. Samples were drawn by a draw step based on a list numbered from 1 to $\mathrm{N}$ of the number of households to be surveyed.

Data collection methods and tools. The data of this study were collected using an openended questionnaire for both qualitative and quantitative information (Balogoun et al., 2016). The information collected related to the socio-demographic characteristics of producers (sex, age, household size, level of education, number of years of experience in sorghum cultivation, types of labor employed, size of farms, areas allocated to sorghum production), indicators of climate change according to farmers and their influence on sorghum cultivation, and the various strategies developed to mitigate the effects of climate change in the areas.

Data processing and analysis. The data collected were coded, entered and processed with the Statistical Package for Social Sciences (SPSS) software, version 20.0 for the determination of descriptive statistics. Quantitative data were subjected to one-way (district) analysis of variance (ANOVA). Comparison of means was done using the Student Newman-Keuls test, at 5\% level of significance (Dagnelie, 1986). According to Bello et al. (2017), in Benin and generally in Africa, local perceptions of events and practices are influenced by ways and customs, which are dependent on sociocultural groups. Therefore, the respondents were grouped according to the eight main socio-cultural groups encountered in the two survey areas, namely the Bambaras, the Bobos, the Sarakolés as well as the Dogons, the Fulani, the Bozos, the Griots and the Blacksmiths. At the level of each group, the respondents were grouped together according to the age categories: young people (people whose age was between 25 and 50 years old); adults (people between 50 and 70 years old) and the elderly (people over or equal to 70 years old). For these two criteria, gender was considered (Assogbadjo et al., 2008) for the assessment of farmers' perceptions. The main socio-cultural groups are presented in Table 2.

For each farmer interviewed, the perception index of each indicator of climate change was determined. An average perception index was calculated for each indicator from the average value of the perception indices of this indicator by the individuals making up the group considered (Bello et al., 2017). The formula used to calculate this index:

$$
\mathrm{Ii}=\frac{X i-X}{s}
$$

Where:

$\mathrm{Xi}=$ value of the annual perception index for year $\mathrm{i}$;

$X=$ interannual average value of the perception index over the period studied; and

$S=$ interannual value of the standard deviation of the perception index over the period studied.

For each of the 23 categories, an average of perception citation was calculated for each indicator from the average value of the citation of perception of this indicator by the individuals in the group considered (Bello et al., 2017). This matrix was subjected to a Principal Component Analysis (PCA) (Bello et al., 2017) in order to describe the existing relationships between farmers' perceptions of climate change and the intensity of manifestation of 
TABLE 2. Numbers associated with the 23 main $y i=x i \beta+\varepsilon i$

socio-cultural groups studied

\begin{tabular}{llr}
\hline Socio-cultural groups & Code & Number \\
\hline Elder Man Bambara & AHB & 81 \\
Young Man Bambara & JHB & 89 \\
Young Woman Bambara & JFB & 48 \\
Aged Woman Sarakole & AFS & 02 \\
Elder Man Bobo & AHBO & 27 \\
Elder Man Bozo & AHBOZO & 5 \\
Aged Woman Bambara & AFB & 10 \\
Elderly Griot Man & AHG & 5 \\
Older Peulh Man & AHP & 4 \\
Elder Man Sarakole & AHS & 10 \\
Senior Men Somono & AHSOM & 8 \\
Young Woman Bobo & JFBO & 12 \\
Young Woman Bozo & JFBOZO & 4 \\
Young Dogon Woman & JFD & 3 \\
Young Woman Blacksmith & JFF & 2 \\
Young Peulh Woman & JFP & 4 \\
Young Woman Sarakole & JFS & 6 \\
Young Woman Somono & JFSOM & 2 \\
Young Woman Bobo & JFBO & 16 \\
Young Woman Bozo & JFBOZO & 4 \\
Young Man Griot & JHG & 2 \\
Young Peulh Man & JHP & 4 \\
Young Man Sarakole & JHS & 4 \\
\hline Total & & 352 \\
\hline & & \\
\hline
\end{tabular}

the different indicators. The same analytical approach linked to the establishment of sociocultural groups was carried out for the identification of adaptation strategies implemented by farmers, in order to mitigate the effects of climate change. For each group, the number of people who opted for each of the coping strategies identified, were calculated. The contingency table obtained was subjected to a simple Correspondence Factor Analysis (CFA) (Gnanglè et al., 2011; Bello et al., 2017). Ultimately, to determine the factors that influence the decision of sorghum producers to develop an adaptation strategy, binary logit regression was used according to the model proposed by Nabikolo et al. (2012):
Where:

yi represents in the equation a dichotomous dependent variable (the variable takes the value 1 if the producer adopts an adaptation strategy in response to perceived climate change and the value 0 otherwise); $x i$ is the set of explanatory variables and åi is the standard error.

The explanatory variables considered are among those reported by different authors (Oyekale and Oladele, 2012; Loko et al., 2013; Bello et al., 2017) as affecting the awareness of climate change by producers.

\section{RESULTS}

Socio-economic characteristics. Tables 3 and 4 present the socio-economic characteristics of the sorghum farmers interviewed in the study areas. In both study areas, the age of the producers surveyed varied between 25 and 93 years and these ages did not vary significantly $(\mathrm{P}>0.05)$ between the two study areas (Table 4). The results of Table 3 show that most $(98.58 \%)$ of the producers were married.

The majority $(98.80 \%)$ of the sorghum fields were owned by indigenous people. Only $35.51 \%$ of surveyed producers were uneducated against $33.81 \%$ literate and $24.44 \%$ primary education level. The number of years of experience in sorghum production varied between 10 to 20 years for $48 \%$ of the respondents. However, more than $51.71 \%$ had more than 20 years of experience in sorghum production.

The number of years of experience in sorghum production did not vary significantly $(P>0.05)$ from one area to another (Table 4). The area cultivated with sorghum varied between 1 to 3 ha. In the two production zones, farmers $(46.88 \%$ in Koulikoro and $44.32 \%$ in San) allocate between 1 to 3 ha for the cultivation of sorghum; but the area 
TABLE 3. Socio-economic characteristics of producers surveyed in Mali

\begin{tabular}{|c|c|c|c|}
\hline \multirow[t]{2}{*}{ Variables } & \multicolumn{3}{|c|}{ Percentage of Respondents (\%) } \\
\hline & Modality & Koulikoro & San \\
\hline Sex & $\begin{array}{l}\text { Male } \\
\text { Female }\end{array}$ & $\begin{array}{l}38.07 \\
11.93\end{array}$ & $\begin{array}{l}36.93 \\
13.07\end{array}$ \\
\hline Age (year) & $\begin{array}{l}<50 \\
>50\end{array}$ & $\begin{array}{l}23.30 \\
26.70\end{array}$ & $\begin{array}{l}24.43 \\
25.57\end{array}$ \\
\hline Education level & $\begin{array}{l}\text { None } \\
\text { Alphabetized } \\
\text { Primary } \\
\text { Fundamental } \\
\text { Arabic } \\
\text { Superior }\end{array}$ & $\begin{array}{r}15.34 \\
15.91 \\
14.77 \\
2.84 \\
0.57 \\
0.57\end{array}$ & $\begin{array}{r}20.17 \\
17.90 \\
7.67 \\
3.13 \\
0.85 \\
0.28\end{array}$ \\
\hline Matrimonial status & $\begin{array}{l}\text { Single } \\
\text { Married } \\
\text { Divorced } \\
\text { Widower }\end{array}$ & $\begin{array}{r}0.28 \\
49.72 \\
0.00 \\
0.00\end{array}$ & $\begin{array}{r}0.28 \\
48.87 \\
0.28 \\
0.57\end{array}$ \\
\hline Origin & $\begin{array}{l}\text { Indigenous } \\
\text { Migrant }\end{array}$ & $\begin{array}{r}49.43 \\
0.57\end{array}$ & $\begin{array}{r}46.02 \\
3.98\end{array}$ \\
\hline Number of years of experience in sorghum cultivation & $\begin{array}{l}10 \text { and } 20 \\
>20\end{array}$ & $\begin{array}{l}23.01 \\
26.99\end{array}$ & $\begin{array}{l}25.28 \\
24.72\end{array}$ \\
\hline Exploited areas (ha) & $\begin{array}{l}<1 \\
1 \text { and } 3 \\
>3\end{array}$ & $\begin{array}{r}0 \\
46.88 \\
3.12\end{array}$ & $\begin{array}{r}0 \\
44.32 \\
5.68\end{array}$ \\
\hline
\end{tabular}

allocated to sorghum cultivation was significantly higher in Koulikoro than in San.

Perceptions of sorghum producers on indicators of climate change. The indicators of climate change and the climatic factors that affect the productivity of sorghum identified during the study were: irregular rains, strong winds, drought, sorghum yield reduction, floods, high temperatures and late or sometimes early onset, as well as the early end of the rainy season, and the sequences of prolonged dry periods. Specifically, the irregularity of the rains, the floods, the early beginnings and the late ends of the rainy seasons are the indicators used by producers in the Sudanian zone. In contrast, in the Sahelian zone, the indicators used relate to drought, high temperatures, strong winds, reduced crop yields and the observation of dry and prolonged sequences during the season.

The results of the principal component analysis carried out on the indicators of appreciation of the manifestations of climate change, indicate that the first three axes explained $62.7 \%$ of the variability noted in the indicators reported by the producers (Fig. 2). The projection of socio-cultural groups and indicators of appreciation of the manifestations of climate change in the factorial plans of the PCA (Fig. 2) reveals that the elderly men of the socio-cultural groups Bobo, Sarakolé, Fulani, Griot, the adult women from the Bambara socio-cultural group, Fulani and young men from the Bambara and Fulani sociocultural groups consider that the late and early 
Climate change and adaptation strategies on sorghum productivity

start of the rainy season, the late end and the dry periods of the season of rains constitute the most important climatic indicators in their environment. The adult Bozo men, the young Bozo and Bobo men, as well as the young Sarakolé and Dogon women, the blacksmiths and the Bobo perceived frequent flooding as indicators of climate change. However, the elderly Bambara and Somono men, the adult women Sarakolé, the young Bozo, Bobo, Bambara and Somono women as well as the young Griot men perceive the manifestations of climate change through the irregularities of the rains, the strong winds, the drought and sorghum yield declines.

Climatic factors affecting sorghum productivity. Figure 3 presents the result of the Correspondence Factor Analysis (CFA) results showing the effect of climatic factors on the phenology of sorghum plants. It emerged from the figure that the climatic factors affecting the productivity of sorghum according to the producers of the two zones were: the irregularity of the rains, late onset of the rains, early end of the rainy season and dry sequences during the season, strong winds, high temperature and sunshine. The irregularities of the rains affected the emergence of the seeds, bolting, heading of the plants, high winds resulting in the fall of the flowers and the high temperatures and the sunshine result in the early flowering and poor grain filling (Fig. 3).

Farmers' strategies for adapting to the effects of climate change. In general, $83.40 \%$ of producers in the two zones practiced adaptation strategies, which varied with the adverse effects of climate change (Fig. 4). Regular radio monitoring of meteorological information (19.89\% of people interviewed) for proper planning of agricultural activities, the use of drought-resistant varieties (13.35\% of people interviewed), application of fertilisers (organic and mineral) to improve the level of crop yield (24.72\% of people interviewed), the application of the Zaï technique $3.41 \%$ of 


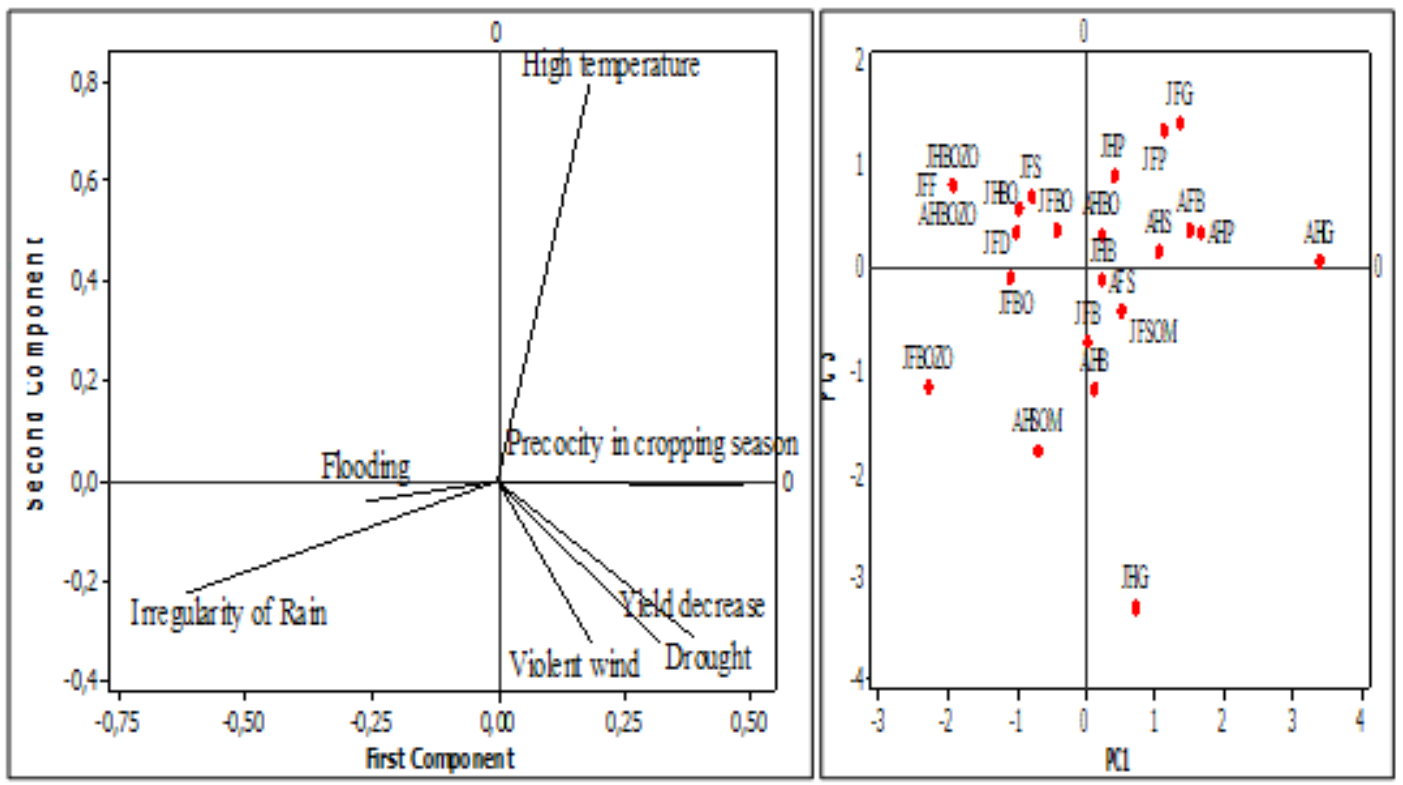

Figure 2. Projection of climate change indicators and socio-cultural groups in the PCA axis factorial plan.

Legend: $\mathrm{AHB}=$ Old Man Bambara; $\mathrm{AFB}=$ Old Woman Bambara; JHB = Young Man Bambara; JFB = Young Woman Bambara; AHS = Old Man Sarakole; AHP = Old Man Fulani; JHS = Young Man Sarakole; AFS= Old Woman Sarakole; JFS= Young Woman Sarakole; JHP = Young Man Fulani; JFP = Young Woman Fulani; AHBOZO = Old Man BOZO; JHBOZO = Young Man BOZO; JFBOZO = Young Woman BOZO; AHBO = Old Man Bobo; JHBO = Young Man Bobo; JFBO = Young Woman Bobo, AHG = Old Man Griot; JHG = Young Man Griot; JFG = Young Woman Griot; AHSOM = Old Man Somono; JFSOM = Young Woman Somono; JFD = Young Woman Dogon.

people interviewed), the installation of stone bunds $(1.7 \%$ of those interviewed) and the prayer sessions and sacrifices to implore the indulgence of the gods so that the rain falls (3.98\% of those interviewed) were the coping strategies among many others practiced by the producers of the two zones.

With regard to high temperatures and sunshine, producers practiced crop associations ( $25.85 \%$ of people interviewed) and mulching ( $2.27 \%$ of people interviewed) to maintain soil moisture around sorghum plants. As for the harmful effects of strong winds, the techniques used were installation of windbreaks $(2.56 \%$ of people interviewed) in sorghum fields and agroforestry $(2.27 \%$ of people interviewed) through the shea butter and African locust bean parks.
The results of the factorial correspondence analysis (CFA) carried out indicate that the different socio-cultural groups such as the old men (Bambara, Somono, Sarakolé), the old women (Bambara), the young men (Bambara) and the young women (Bobos and Dogons) rely on meteorological information broadcast by local radio stations, the adoption of seeds from drought-resistant varieties, the practice of mulching with crop residues, the application of organic fertilisers and Zaï techniques to mitigate the effects of climate changes for good sorghum production (Fig. 5). The elderly Griots, Bozo, Bobo and the young Sarakolés, Bobos and Bozos; young women Sarakolés, Fulani, Bambaras, Somonos, Bozos, and blacksmiths practiced intercropping as strategies of adaptation against the harmful 

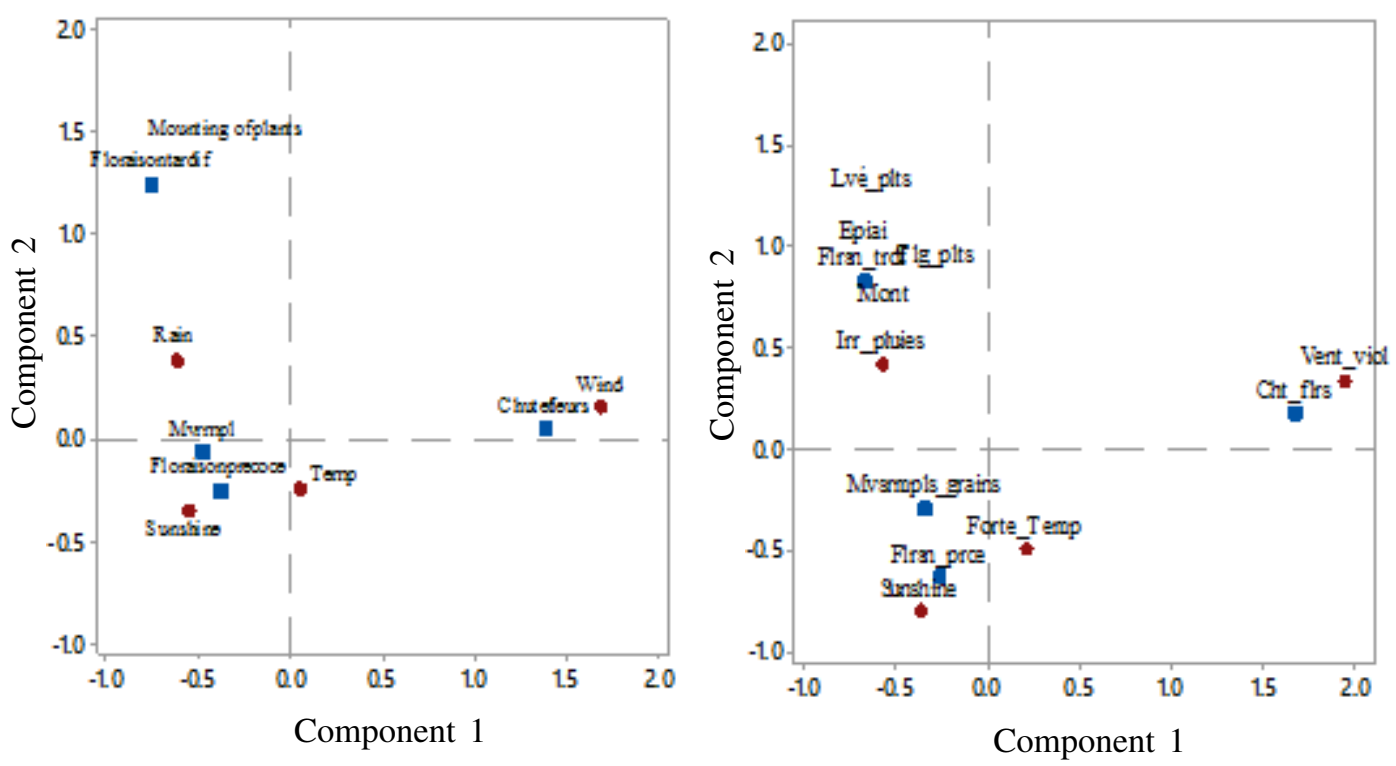

Figure 3. Effect of climatic factors on the phenology of sorghum plants in Mali.

Legend: Irré-pluies = Irregularity of the rains; Vent-Viol = strong wind; Forte-Temp = high temperature; Florai-tard = late flowering; Mauvai-Lvés-montai-épisai-plants = Bad rising, rising and heading of the plants; Cht-fleurs = Fall of the flowers; Florai-précoce $=$ Early flowering; Mauvai-remplis = Bad filling of the seeds.

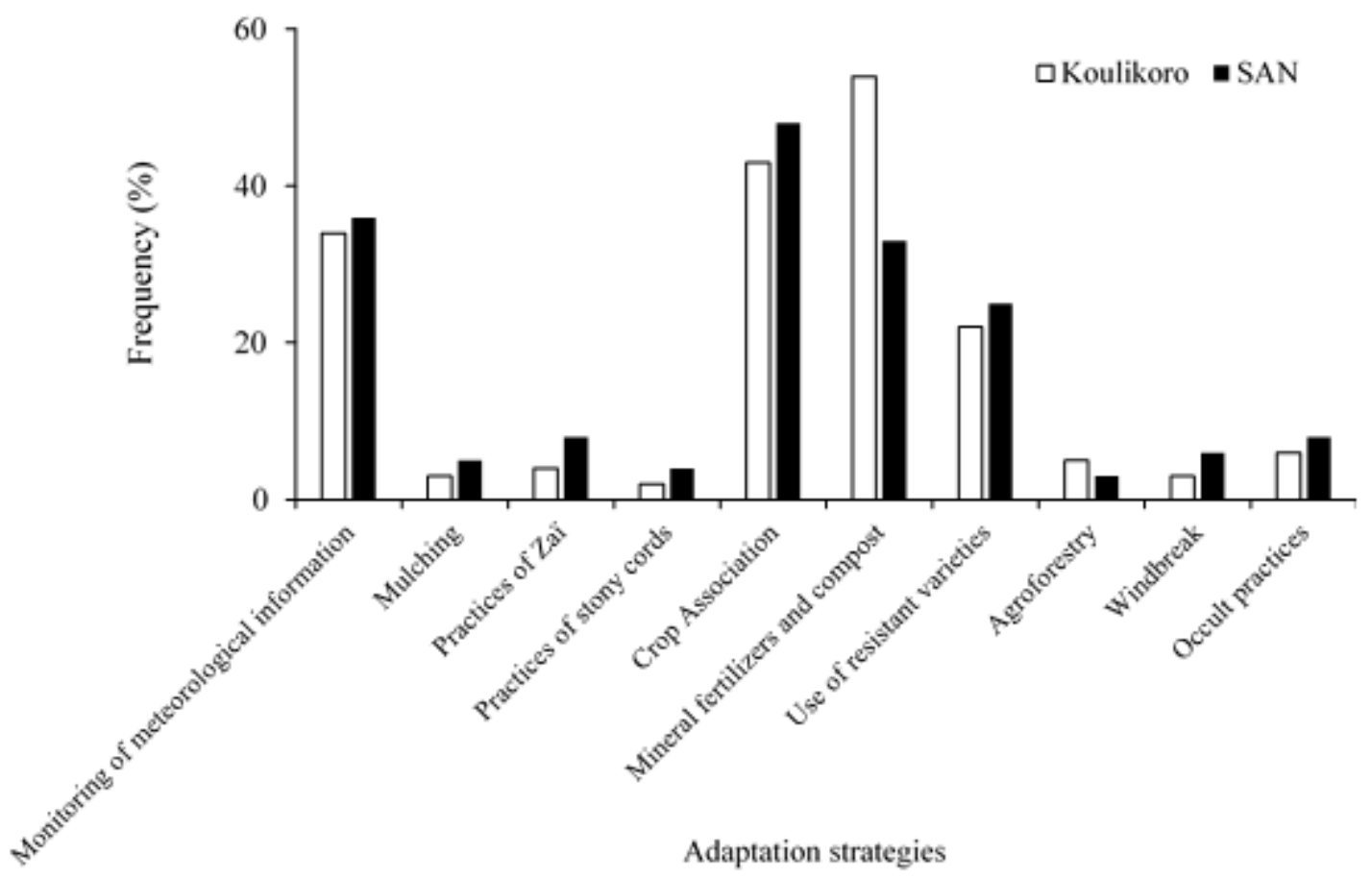

Figure 4. Adaptation strategies implemented by sorghum producers in Mali in response to variability climatic factors. 


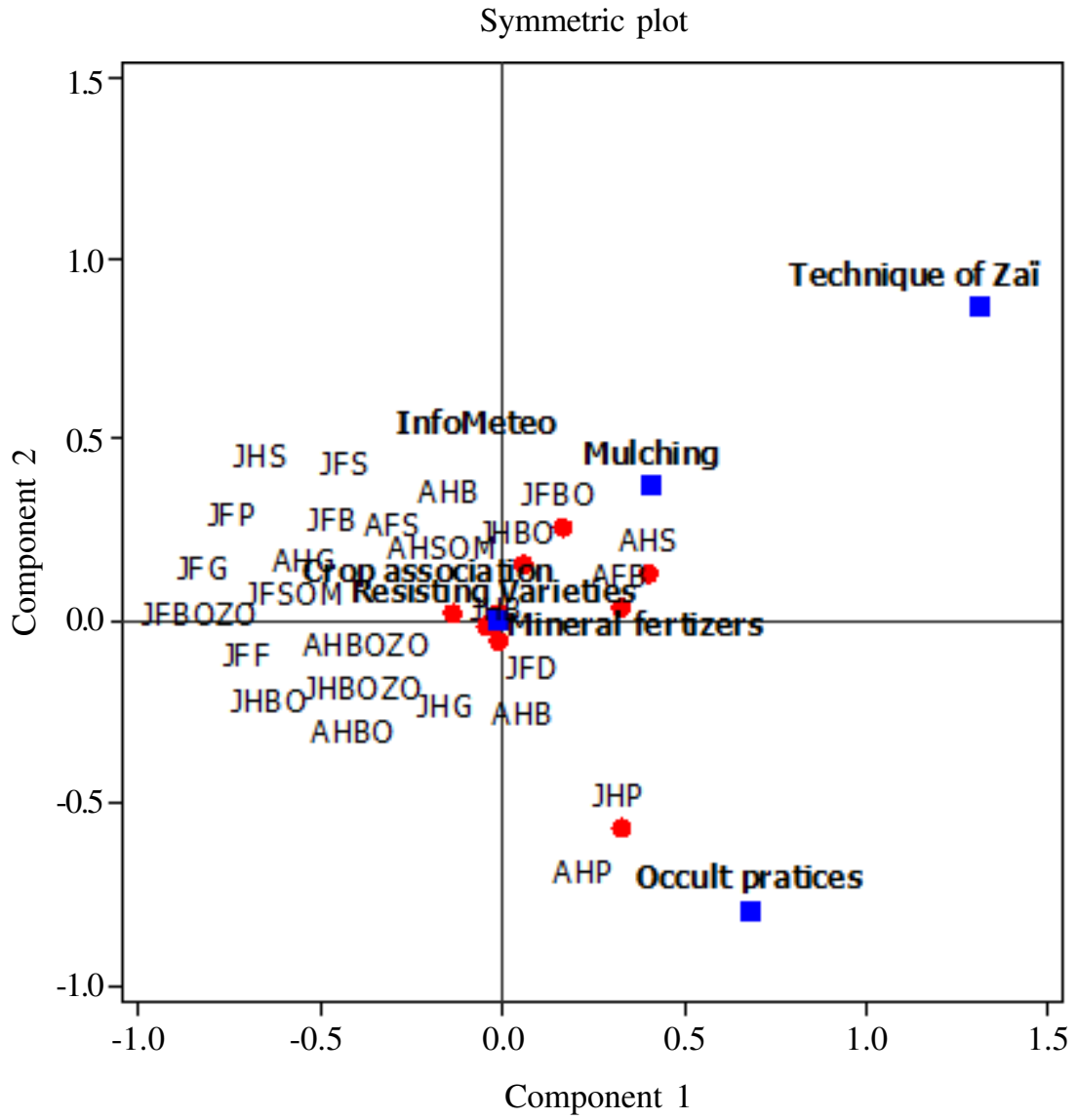

Figure 5. Projection of adaptation strategies in the factorial system axis resulting from Correspondence Factor Analysis (CFA).

Legend : Infometeo = Monitoring of meteorological information; $\mathrm{AHB}=$ Old Man Bambara $; \mathrm{AFB}=\mathrm{Old}$ Woman Bambara; JHB = Young Man Bambara; JFB = Young Woman Bambara; AHS = Old Man Sarakole; AHP = Old Man Fulani, JHS = Young Man Sarakole; AFS = Old Woman Sarakole; JFS = Young Woman Sarakole; JHP = Young Man Fulani; JFP = Young Woman Fulani; AHBOZO = Old Man $\mathrm{BOZO}$; JHBOZO = Young Man BOZO; JFBOZO = Young Woman BOZO; AHBO = Old Man Bobo; JHBO = Young Man Bobo; JFBO = Young Woman Bobo, AHG = Old Man Griot; JHG = Young Man Griot; JFG = Young Woman Griot; AHSOM = Old Man Somono; JFSOM = Young Woman Somono; JFD = Young Woman Dogon.

effects of climate change. Finally, sociocultural groups such as elderly Fulani men and young men practiced different forms of beliefs for making rain falls. However, mulching, Zaï and stone bunds were more used in the Sahelian zone than the Sudanese zone.

Determinants of the adoption of adaptation strategies. The results of the binary logistic regression analysis (Table 5) revealed that among the 13 explanatory variables considered, only the number of male agricultural workers in the household, the number of years of experience of producers in the sorghum cultivation, the source of finance for sorghum production and the use of varieties resistant to climate variability very significantly influenced $(\mathrm{P}<0.001)$ the adoption 
TABLE 5. Determinants of the adoption of climate change adaptation strategies by sorghum farmers in the study area in Mali

\begin{tabular}{lcr}
\hline Explicative variables & Chi-2 & P \\
\hline Age & $1.13 \mathrm{~ns}$ & 0.88 \\
Level of education & $1.31 \mathrm{~ns}$ & 0.53 \\
Number of years of experience in sorghum cultivation & $1.24 * *$ & $<004$ \\
Number of active men in the household & $0.989 *$ & $<0.03$ \\
Number of working women in the household & $2.60 \mathrm{~ns}$ & 0.98 \\
Area available for agriculture & $1.43 \mathrm{~ns}$ & 0.74 \\
Surface area exploited & $3.23 \mathrm{~ns}$ & 0.72 \\
Area allocated to sorghum cultivation & $3.91 \mathrm{~ns}$ & 0.43 \\
Contribution of sorghum to household income & $3.29 \mathrm{~ns}$ & 0.26 \\
Source of income & $>99.99 * * *$ & $<001$ \\
Variety of sorghum used & $>99.99 * * *$ & $<001$ \\
Mystical beliefs & $3.38 \mathrm{~ns}$ & 0.07 \\
\hline
\end{tabular}

$*$ : significant at the 0.05 cut-off; $* *$ : very significant at the 0.05 cut-off; $* * *$ : very highly significant at the 0.05 cut-off

of a strategy to adapt to the adverse effects of climate change. Married sorghum farmers who had more experience in sorghum production and had sources of finance for growing sorghum, readily adopted coping strategies.

\section{DISCUSSION}

Socio-economic characteristics of sorghum producers. In both districts men grew more sorghum than women (Table 3), this is due to the fact that sorghum is the main crop for food security like maize and rice in the Sudanian zone of West Africa. All of these crops are grown mainly by men (Toléba-Séidou et al., 2017) to satisfy family food needs. These cereal crops require inputs for yield improvement. Women do not have easy access to land and yet they inherit poor land (Saïdou et al., 2012). However, women are devoted to cultivation of legume crops especially groundnut (Chabi et al., 2019), crops with less nutritional requirements. The age of respondents varied between 25 and 93 years. This shows that sorghum cultivation is an activity of all age groups in Mali. This could well be explained by the importance given to sorghum by the populations in their diets (Sissoko et al., 2018). This is evidenced by the strong experience in sorghum production noted at the producers' level. Most of respondents had between 23 and 25 years of experience in sorghum. These results are consistent with the findings of many other researchers (Uwagboe et al., 2010; Balogoun et al., 2014; Chabi et al., 2019).

The area allocated to sorghum cultivation on farms in Koulikoro was significantly higher than in San. This could be explained by the climatic conditions prevailing in both zones. San zone has a Sahelian climate, which means that the number of rainy days is lower compared to that of Sudanese zone (Koulikoro) and, therefore, the risk of climatic hazards (Kouressy et al., 2008) is very high in San compared to Koulikoro.

Relevance of climate change parameters and indicators. The study generally revealed that, the irregularity of the rains, the late start and the early end of the rains, the dry sequences observed during the season, the prolonged droughts and the floods are recurrent phenomena in the study area (Fig. 
2). Other researchers (Cooper et al., 2008; Deressa et al., 2011; Simelton et al., 2013; Rurinda, 2014; Traoré et al., 2015; Sissoko et al., 2017) also came to similar conclusions. These climatic variables have a direct influence on the productivity of crops in general. This negative influence is reflected in particular by poor emergence of sown seeds, reduction in tillering of plants, poor bolting and heading, flower drop and poor grain filling (Traoré $e t$ al., 2011; Traoré et al., 2011; Traoré et al., 2015). These consequences were also reported by the producers surveyed. They then appear more memorable and visible to producers than other climatic parameters such as potential evapotranspiration (PET), duration of sunstroke and relative humidity (Bello et al., 2017).

With respect to temperature, respondents reported rise in heat compared to decades ago (Fig. 2). According to them, this rise in temperature was linked to the increase in the duration of dry spells during the rainy season. These observations were also reported by several other workers (McCarthy and Vlek, 2012; Traoré et al., 2015; Sissoko et al., 2017). Likewise, sorghum flower drops and lodging of stems due to high winds were also reported by farmers as a result of the effects of climate change (Sissoko et al., 2017).

The decline in sorghum productivity reported by producers, as an indicator of the impact of climate change, has also been mentioned on many crops (Loko et al., 2013; Balogoun et al., 2016; Bello et al., 2017). Irregular rains, late onset and early cessation of rains, followed by dry sequences during the season, droughts and floods were reportedly the most important indicators of climate change, commonly mentioned by sorghum producers compared to high temperatures and winds. These different perceptions can be explained by the fact that factors related to water management for agricultural production are perceived as the most important because they influence the productivity of sorghum (Traoré et al., 2015; Sissoko et al., 2017).

Similar farmers' perceptions have been reported by several studies (Nelson et al., 2010; Yabi and Afouda, 2012; Antwi-Agyei et al., 2014). This indicates a similarity of perceptions from one region to another in Africa, especially when land productivity is affected. In this context, technologies for better adaptation of sorghum production in the study area should allow for improvement in water use efficiency by sorghum plants. Adjustment in sowing dates, combined with use of resistant varieties, are avenues that can be explored in order to achieve results to this end.

Adaptation and mitigation strategies. Faced with all these manifestations of climate today, sorghum producers have developed various adaptation strategies to improve crop productivity. These strategies focus on improving cultivation practices, soil and water conservation techniques and the use of improved short-cycle and drought-resistant varieties (Fig. 4).

It was also noted that some producers resorted to religious beliefs, that is, the invocation of divine mercy through sacrifices and the organisation of prayers in order to make rain falls. The latter practice has also been variously observed in other regions of Africa (Nyanga et al., 2011; Luka and Yahaya, 2012; Tazeze et al., 2012; Loko et al., 2013). Indeed, in many parts of Africa, the manifestations of climate change is still perceived as divine punishment, against which humans are powerless and only divine invocation can save them. According to Tidjani and Akponikpe (2012) and Bello et al. (2017), these different adaptation practices to climate change must be seen as preventive or curative measures. Producers have always known how to adapt to these climatic risks; but the effectiveness of adaptation measures remains limited, and external research support based 
on the knowledge of these producers would allow for effective support.

The adaptation measures adopted by sorghum producers varied according to the socio-cultural groups, sex, age and socioeconomic activities of producers (Fig. 5). In Mali and more generally in Africa, the perceptions of local populations to the phenomena and the practices developed as a result are very much influenced by habits and customs, which depend on the beliefs of sociocultural groups (Gnanglè et al., 2011). It is, therefore, important to take these different points of view into account in the implementation of adaptation strategies so that they are accepted by all sorghum producers.

In general, the adaptation measures adopted to deal with climate change are almost similar to those observed in other Sahel countries as mentioned by Sissoko et al. (2017). So this implies that the technologies implemented in Mali can work well in other areas of the Sahel. Sissoko et al. (2017) proposed several strategies to be used in Mali to reduce the vulnerability of sorghum cultivation to climate change. These include water and soil management, use of inputs to increase crop resistance, improved drought-resistant varieties, filter bunds, vegetated strips, recovery systems of water, crossed ridges or contour lines, micro-zones of water retention, and microdosing of fertilisers. All these measures have demonstrated effectiveness in improving crop yields, especially in the Sahelian zone (Sissoko et al., 2017). The practices provide tangible proof of their adoption by rural communities. It would then be judicious to evaluate their agronomic efficiency for sustainable production of sorghum in the country.

Determinants of the adoption of adaptation practices. Four main factors (number of active agricultural men in the household, number of years of experience in sorghum production, sources of producer finance and use of improved and drought resistant varieties) determine producers' choice of adoption of adaptation measures to climate change (Table 5). Indeed, the higher the number of active agricultural men in the household, the more land is devoted to agriculture because of the large workforce provided. This often leads to adoption of modern production techniques and is also more favourable to the implementation of adaptation strategies. These results suggest that capital, land and labour serve as important factors for coping with and adapting to climate change (Hassan and Nhemachena, 2008).

The fact that the producer's sources of income had an influence on the producer's ability to adopt adaptation strategies could be explained by the fact that credits are investments that must be profitable at all costs and, therefore, all measures must be implemented to ensure good productivity.

Better access to extension and credit services seem to have a strong positive influence on the probability of adopting all adaptation measures and abandoning the relatively risky monocropping systems. According to Akponikpè and Tidjani (2012), Dansi et al. (2013), the use of cultivars resistant to drought and water deficit seems to be an effective strategy to climate change. This could explain why sorghum growers are drought-resistant varieties to cope with the effects of climate change.

Our findings differ from those Tazeze $e t$ al. (2012) in Ethiopia, Oyekale and Oladele (2012) in Nigeria, Loko et al. (2013) and Bello et al. (2017) in Benin. However, these authors obtained similar results with regard to the number of years of experience of producers in the production of the crop as a determining factor in the choice of an adaptation strategy. According to Falola et al. (2012), the fact that sorghum producers acquire and develop more skills over time allows them to uptake adaptive measures against the impact of climate change. The more experienced farmers are more likely to adapt than the less experienced ones (Hassan and Nhemachena, 2008; Bello et al., 2017). More farming experience was found 
to promote adaptation. Experienced farmers usually have better knowledge and information on climate change and agronomic practices that they can use to cope with changes in climate and other socioeconomic conditions (Hassan and Nhemachena, 2008).

Our results are similar to those of Hassan and Nhemachena (2008) and Bello et al. (2017) who showed that age and sex are not always determining factors in the adaptation strategies developed at the local level, but rather it is the experience of agricultural producers and the capacities of households to access to credit and the market which are crucial.

The study by Deressa et al. (2011) in Ethiopia and that of Salhi et al. (2012) in Algeria presented non-analogous results and reveal that the level of education of the producer would also increase the probability of adaptation to climate change. Emphasis will be placed on all of these factors in the rest of the study aimed at evaluating the agronomic effectiveness of adaptation strategies.

\section{CONCLUSION}

This study has shown that the effect of climate change and its negative consequences on sorghum productivity are perceived by sorghum producers in the study area. The irregularity of the rains and its poor distribution, the increase in temperature and strong winds, floods, prolonged droughts, the late onset and early cessation of the rains, the dry stretches during the season and the drop in yields are the climate change indicators mentioned by sorghum producers in the two study areas.

The number of years of experience in cultivating sorghum as well as the number of agricultural workers in the household are the factors that lead sorghum producers to adopt strategies to adapt to climate change. This highlights the consideration of the conditions and status of producers in the development of technologies for adaptation to climate change. Emphasis must be placed on current cultivation practices in the area to ensure effective ownership of the strategies. This will promote good productivity of sorghum, an important crop in the Sahelian zone.

\section{ACKNOWLEDGEMENT}

The authors thank the Capacity Building Project for Higher Education Institutions in Integrated Water Resources Management (IES4GIRE NICHE_MLI_251) in Mali and the Kingdom of the Netherlands for funding this work.

\section{REFERENCES}

Antwi-Agyei, P., Stringer, L.C. and Dougill, A.J. 2014. Livelihood adaptations to climate variability: Insights from farming households in Ghana. Regional Environmental Change 14:1615-1626.

Assogbadjo, A.E., Kakaï, R.G., Chadare, F., Thomson, L., Kyndt, T., Sinsin, B. and Van Damme, P. 2008. Folk classification, perception, and preferences of baobab products in West Africa: Consequences for species conservation and improvement. Economic Botany 62:74-84.

Balogoun, I., Ahoton, L., Saidou, A., Bello, D., Ezin, V., Amadji, G., Ahohuendo, B., Babatounde, S., Chougourou, D. and Ahanchede, A. 2016. Effect of climatic factors on cashew (Anacardium Occidentale L.) productivity in Benin (West Africa). Journal Of Earth Science \& Climatic Change 7:1-10.

Bambara, D., Bilgo, A., Hien, E., Masse, D., Thiombiano, A. and Hien, V. 2013. Perceptions paysannes des changements climatiques et leurs conséquences socioenvironnementales à Tougou et Donsin, climats sahélien et sahélo-soudanien du Burkina Faso. Bulletin de la Recherche Agronomique du Bénin 74:8-16.

Barnabás, B., Jäger, K. and Fehér, A. 2008. The effect of drought and heat stress on reproductive processes in cereals. Plant, Cell \& Environment 31:11-38. 
Bazile, D. and Soumare, M. 2004. Gestion spatiale de la diversité variétale en réponse a la diversité ecosystémique: le cas du sorgho [Sorghum bicolor (L.) Moench] au mali. Cahiers Agricultures 13:480-487.

Bello, D., Ahoton, L., Saidou, A., Akponikpè, I., Ezin, V., Balogoun, I. and Aho, N. 2017. Climate change and cashew (Anacardium Occidentale L.) productivity in Benin (West Africa): Perceptions and endogenous measures of adaptation. International Journal of Biological and Chemical Sciences 11:924-946.

Chabi, F.O., Dagbenonbakin, G.D., Oussou, B. and Saïdou, A., 2019. Determinant of groundnut (Arachis hypogaea L.) yield improvement in the farmers' cropping systems in Benin. African Journal of Agricultural Research 14(34): 1967-1979. doi: 10.5897/AJAR2019.14418

Cooper, P., Dimes, J., Rao, K., Shapiro, B., Shiferaw, B. and Twomlow, S. 2008. Coping better with current climatic variability in the rain-fed farming systems of sub-saharan africa: an essential first step in adapting to future climate change? Agriculture, Ecosystems \& Environment 126:24-35.

Dagnelie, P. 1986. Théorie et méthodes statistiques. Applications agronomiques. Volume 2. Les Presses Agronomiques De Gembloux, Belgique. 463pp.

Dagnelie, P. 1998. Statistique Théorique Et Appliquée. Tome 2. Inférence Statistique à Une Et A Deux Dimensions. De Boeck Université, Paris, France. 659pp.

Deressa, T.T., Hassan, R. M. and Ringler, C. 2011. Perception of and Adaptation to climate change by farmers in the Nile Basin of Ethiopia. The Journal of Agricultural Science 149:23-31.

Dimon, R. 2008. Adaptation aux changements climatiques: Perceptions, savoirs locaux et stratégies d'adaptation développées par les producteurs des communes de Kandi et de Banikoara, au Nord du Bénin. Thèse De Doctorat. Université d'Abomey-Calavi, Bénin. 209pp.
Faostat 2018. http://Www.Fao.Org/Faostat/ En/\#Data/QC.Consulté le 18/01/2020.

GIEC 2014. Changements climatiques 2014: L'atténuation du changement climatique. Contribution du Groupe de travail III au cinquième Rapport d'évaluation du Groupe d'experts intergouvernemental sur l'évolution du climat. Edenhofer, O., PichsMadruga, R., Sokona, S., Mix, J.C., Farahani, E., Kadner, S., Seyboth, K., Adler, A., Baum, I., Brunner, S., Eickemeir, P., Krieman, B., Savolainen, J., Schlömer, S., von Stechow, C. and Zwickel, T. (dir. publ)] Cambridge University Press, Cambridge, UK. 180pp.

Gnanglè, C. P., Glèlè Kakaï, R., Assogbadjo, A.E., Vodounnon, S., Afouda Yabi, J. and Sokpon, N. 2011. Tendances climatiques passées, modélisation, perceptions et adaptations locales au Bénin. Climatologie 8:27-40.

Hassan, R.M. and Nhemachena, C. 2008. Determinants of African farmers' strategies for adapting to climate change: Multinomial choice analysis. African Journal of Agricultural and Resource Economics 2:83-104.

Kanté, S. 2001. Gestion de la fertilité des sols par classe d'exploitation au Mali-Sud. PhD. Université de Wageningen, Pays-Bas. 239pp.

Loko, Y., Dansi, A., Agre, A., Akpa, N., Dossou-Aminon, I., Assogba, P., Dansi, M., Akpagana, K. and Sanni, A. 2013. Perceptions paysannes et impacts des changements climatiques sur la production et la diversité variétale de l'igname dans la zone aride du Nord-Ouest du Bénin. International Journal of Biological and Chemical Sciences 7: 672-695.

Luka, E.G. and Yahaya, H. 2012. Perceived constraints to use of indigenous soil management practices among yam producers in Nasarawa State, Nigeria. Journal of Sustainable Development in Africa 14:1520-5509.

Mccarthy, D. and Vlek, P.L. 2012. Impact of climate change on sorghum production 
under different nutrient and crop residue management in semi-arid region of Ghana: A modeling perspective. African Crop Science Journal 20:243-259.

Mustapha, S., Sanda, A. and Shehu, H. 2012. Farmers' perception of climate change in central agricultural zone of Borno State, Nigeria. Journal of Environment and Earth Science 2:21-27.

Nabikolo, D., Bashaasha, B., Mangheni, M. and Majaliwa, J. 2012. Determinants of climate change adaptation among male and female headed farm households in Eastern Uganda. African Crop Science Journal 20: 203-212.

Nelson, R., Kokic, P., Crimp, S., Martin, P., Meinke, H., Howden, S., De Voil, P. and Nidumolu, U. 2010. The vulnerability of Australian rural communities to climate variability and change: Part Ii-Integrating impacts with adaptive capacity. Environmental Science \& Policy 13:18-27.

Nyanga, P.H., Johnsen, F.H. and Aune, J.B. 2011. Smallholder farmers' perceptions of climate change and conservation agriculture: evidence from Zambia. Journal of Sustainable Development 4(4):73-85.

Oyekale, A. and Oladele, O. 2012. Determinants of climate change adaptation among cocoa farmers in Southwest Nigeria. ARPN Journal of Science and Technology 2:154-168.

Roncoli, C., Kirshen, P., Ingram, K. and Jost, C. 2001. Burkina Faso-Integrating indigenous and scientific rainfall forecasting. Open Knowledge Repository 39: 4.

Rurinda, J. 2014. Vulnerability and adaptation to climate variability and change in smallholder farming systems in Zimbabwe. Phd. Wageningen University, Pays-Bas. 180pp.

Saïdou, A., Balogoun, I., Ahoton, E., Igué, A., Youl, S., Ezui, G. and Mando, A. 2018. Fertilizer recommendations for maize production in the South Sudan and SudanoGuinean zones of Benin. Nutrient Cycling in Agroecosystems 110:361-373.
Saïdou, A., Kossou, D., Acakpo, C., Richards, P. and Kuyper, T.W. 2012. Effects of farmers' practices of fertilizer application and land use types on subsequent maize yield and nutrient uptake in Central Benin. International Journal of Biological and Chemical Sciences 6:365-378.

Salhi, S., Imache, A., Tonneau, J.P. and Ferfera, M.Y. 2012. Les déterminants de l'adoption du système d'irrigation par goutte-a-goutte par les agriculteurs algériens de la plaine de la Mitidja. Cahiers Agricultures 21(1):417-426.

Schmidhuber, J. and Tubiello, F. N. 2007. Global food security under climate change. Proceedings of the National Academy of Sciences 10419703-19708.

Simelton, E., Quinn, C.H., Batisani, N., Dougill, A.J., Dyer, J.C., Fraser, E.D., Mkwambisi, D., Sallu, S. and Stringer, L.C. 2013. Is rainfall really changing? Farmers' perceptions, meteorological data, and policy implications. Climate and Development 5:123-138.

Sissoko, K., Savadogo, K., Vaksmann, M. and Tiemtore, A. 2018a. Cereal crops choices and economic resilience face to climate variability in Southern Mali. Journal of Agriculture and Environmental Sciences 7:116-126.

Sissoko, P., Aune, J. B., Senneväg, G., Teme, B. and Lebailly, P. 2017. Vulnerability evaluation of Millet and sorghum cropping system to climate change and adoption of new technologies in Mali. Asian Journal of Science and Technology 8:4176-4182.

Sissoko, P., Berti, F., Gry, S. and Lebailly, P. 2018b. Effets de l'adoption de la technique du microdosage d'engrais sur la disponibilite et l'accessibilite céréalière des exploitations agricoles à base de mil et de sorgho au Mali. Agronomie Africaine 30:193-204.

Sultan, B., Guan, K., Kouressy, M., Biasutti, M., Piani, C., Hammer, G., Mclean, G. and Lobell, D. B. 2014. Robust features of future climate change impacts on sorghum 
yields in West Africa. Environmental Research Letters 9(10):1-13.

Tazeze, A., Haji, J. and Ketema, M. 2012. Climate change adaptation strategies of smallholder farmers: the case of Babilie District, East Harerghe zone of Oromia Regional State of Ethiopia. Journal of Economics and Sustainable Development $3: 1-12$.

Tidjani, M. and Akponikpe, P. 2012. Evaluation des stratégies paysannes d'adaptation aux changements climatiques: Cas de la production du maïs au Nord-Bénin. African Crop Science Journal 20:425-441.

Saïdou, A., Tossou, R., Kossou, D., Sambieni, S., Richards, P. and Kuyper, T.W. 2007. Land tenure and sustainable soil fertility management in Benin. International Journal of Agricultural Sustainability 5(2\&3):195-212.

Toure, H.A., Traore, K., Serme, I. and Ouattara, K. 2018. Organic and inorganic fertilizers induced yield increment of two pearl millet varieties in sudanian and sahelian agro-ecological zones in Mali. Journal of Agricultural Studies 6:158-173.

Traoré, B. 2014. Climate change, climate variability and adaptation options in smallholder cropping systems of the sudano-sahel region in West Africa. PhD. Wageningen University, Pays-Bas. 163pp. Traoré, B., Van Wijk, M.T., Descheemaeker, K., Corbeels, M., Rufino, M.C. and Giller, K.E. 2015. Climate variability and change in Southern Mali: learning from farmer perceptions and on-farm trials. Experimental Agriculture 51:615-634.

Traoré, S.B., Alhassane, A., Muller, B., Kouressy, M., Somé, L., Sultan, B., Oettli, P., Siéné Laopé, A.C., Sangaré, S. and Vaksmann, M. 2011. Characterizing and modeling the diversity of cropping situations under climatic constraints in West Africa. Atmospheric Science Letters 12:89-95.

Traoré, S.B., Reyniers, F.N., Vaksmann, M., Bather, K., Sidibé, A., Yoroté, A., Yattara, K. and Kouressy, M. 2001. Adaptation à la sécheresse des écotypes locaux de sorghos $\mathrm{du}$ Mali. Science et Changements Planétaires/Sécheresse 11: 227-37.

Tschakert, P. 2007. Views from the vulnerable: understanding climatic and other stressors in the Sahel. Global Environmental Change 17:381-396.

Yabi, I. and Afouda, F. 2012. Extreme rainfall years in Benin (West Africa). Quaternary International 262:39-43. 